Article

\title{
Nitrogen and sulfur dual-doped high-surface-area hollow carbon nanospheres for efficient $\mathrm{CO}_{2}$ reduction
}

\author{
Guodong Li a,b, Yongjie Qin b, Yu Wu a,b, Lei Pei ${ }^{b}$, Qi Hu b, Hengpan Yang b, Qianling Zhang b, \\ Jianhong Liu ${ }^{b}$, Chuanxin $\mathrm{He}^{\mathrm{b}, *}$ \\ a Department of Chemical Physics, University of Science and Technology of China, Hefei 230026, Anhui, China \\ b Shenzhen Key Laboratory for Functional Polymer, College of Chemistry and Environmental Engineering, Shenzhen University, Shenzhen 518060, \\ Guangdong, China
}

\section{A R T I C L E I N F}

\section{Article history:}

Received 25 September 2019

Accepted 29 October 2019

Published 5 May 2020

\section{Keywords:}

High specific surface area

Hollow structure

Carbon-based catalysts

$\mathrm{CO}_{2}$ reduction reaction

Electrocatalytic selectivity

\begin{abstract}
A B S T R A C T
The electrochemical reduction of $\mathrm{CO}_{2}\left(\mathrm{CO}_{2} \mathrm{RR}\right)$ can substantially contribute to the production of useful chemicals and reduction of global $\mathrm{CO}_{2}$ emissions. Herein, we presented $\mathrm{N}$ and $\mathrm{S}$ dual-doped high-surface-area carbon materials (SZ-HCN) as $\mathrm{CO}_{2} \mathrm{RR}$ catalysts. $\mathrm{N}$ and S were doped by one-step pyrolysis of a $\mathrm{N}$-containing polymer and $\mathrm{S}$ powder. $\mathrm{ZnCl}_{2}$ was applied as a volatile porogen to prepare porous SZ-HCN. SZ-HCN with a high specific surface area $\left(1510 \mathrm{~m}^{2} \mathrm{~g}^{-1}\right)$ exhibited efficient electrocatalytic activity and selectivity for $\mathrm{CO}_{2} \mathrm{RR}$. Electrochemical measurements demonstrated that SZ-HCN showed excellent catalytic performance for $\mathrm{CO}_{2}$-to-CO reduction with a high CO Faradaic efficiency ( 93\%) at -0.6 V. Furthermore, SZ-HCN offered a stable current density and high CO selectivity over at least $20 \mathrm{~h}$ continuous operation, revealing remarkable electrocatalytic durability. The experimental results and density functional theory calculations indicated that $\mathrm{N}$ and $\mathrm{S}$ dual-doped carbon materials required lower Gibbs free energy to form the $\mathrm{COOH}^{*}$ intermediate than that for single-N-doped carbon for $\mathrm{CO}_{2}$-to-CO reduction, thereby enhancing $\mathrm{CO}_{2} \mathrm{RR}$ activity.
\end{abstract}

(C) 2020, Dalian Institute of Chemical Physics, Chinese Academy of Sciences. Published by Elsevier B.V. All rights reserved.

\section{Introduction}

Over the past several decades, fossil fuels have underpinned the global energy, leading to the ever-growing concentration of $\mathrm{CO}_{2}$ in the atmosphere [1]. Among $\mathrm{CO}_{2}$ conversion approaches, the electrocatalytic $\mathrm{CO}_{2}$ reduction reaction $\left(\mathrm{CO}_{2} \mathrm{RR}\right)$ into valuable chemicals or fuels has been widely considered as a promising carbon-neutral route for suitable and capable catalytic techniques [2-4]. However, the applicability of $\mathrm{CO}_{2} \mathrm{RR}$ is limited because of the high kinetic barriers and the inevitable competition with the hydrogen evolution reaction (HER) [5-7].

Numerous catalysts have been extensively investigated for
$\mathrm{CO}_{2} \mathrm{RR}$, such as noble metals (e.g., Ag, $\mathrm{Au}, \mathrm{Pt}$, and $\mathrm{Pd}$ ) [8-11], alloys (Pt-Au, $\mathrm{Au}-\mathrm{Cu}$, and $\mathrm{Pd}-\mathrm{Sn}$ ) [12-14], metal oxides (CuO, $\mathrm{SnO}_{2}$, and $\mathrm{Bi}_{2} \mathrm{O}_{3}$ ) [15-17], and metallic complexes ( $\mathrm{Ru}, \mathrm{Ir}$, and Pd complexes) [18-20]. These electrocatalysts are capable of reducing $\mathrm{CO}_{2}$ to various products through a multi-electron transfer process, including $\mathrm{CO}, \mathrm{HCOOH}, \mathrm{CH}_{4}$, high-order hydrocarbons, and oxygenates [21-23]. Among these products, CO has attracted considerable attention as an important feedstock for the production of liquid hydrocarbons via the well-known Fischer-Tropsch process $[24,25]$. For the conversion of $\mathrm{CO}_{2}$ to $\mathrm{CO}$, noble metals (e.g., $\mathrm{Au}, \mathrm{Ag}$, and Pd) as catalysts have demonstrated excellent activity and high selectivity of $\mathrm{CO}_{2} \mathrm{RR}$ [26-28].

\footnotetext{
* Corresponding author. Tel: +86-0755-26534173; Fax: +86-755-26536141; E-mail: hecx@szu.edu.cn

This work was supported by the National Natural Science Foundation of China (21574084, 21571131), the Natural Science Foundation of Guangdong (2017A040405066), and Shenzhen Government's Plan of Science and Technology (JCYJ20160308104704791, JCYJ20170818091657056).

DOI: S1872-2067(19)63485-6 | http://www.sciencedirect.com/science/journal/18722067 | Chin. J. Catal., Vol. 41, No. 5, May 2020
} 
However, high cost, low stability, and potential environmental toxicity limit the large-scale application of noble metal catalysts. Recently, metal-free carbon materials have been explored as alternative catalysts for $\mathrm{CO}_{2}$-to-CO reduction because of their low cost, tunable porous structures, high surface area, and easy incorporation of heteroatoms [29-31]. For instance, heteroatom-doped graphene, carbon fibers, carbon nanotubes, nanoporous carbon, and diamond materials exhibit $\mathrm{CO}_{2} \mathrm{RR}$ activity and stability comparable to those of noble metals [32-36]. Among these materials, nanoporous carbon with characteristic features such as controlled nanostructures and high specific surface (SSA) and porosity may facilitate mass transport and abundant active sites in the $\mathrm{CO}_{2} \mathrm{RR}$ process [37-40]. Although conventional approaches have been widely employed for the synthesis of nanoporous carbon (hard template, soft template, and activation methods), these methods offer certain disadvantages, such as the use of hazardous chemicals (hydrofluoric acid or hot alkaline solution) and time-consuming process [41-44]. In addition, the incorporation of heteroatoms (N, B, S and P) into porous carbon could result in asymmetric electron spin density and charge redistribution, which could increase intrinsic activity [45-50]. Therefore, the development of a useful and accessible route to obtain high-surface-area porous heteroatom-doped carbon materials and efficient electrocatalytic performance toward $\mathrm{CO}_{2} \mathrm{RR}$ is still desirable.

Herein, a facile and effective strategy is developed for synthesizing N, S dual-doped high-surface-area hollow carbon materials (denoted as SZ-HCN) by one-step pyrolysis of a N-doped polymer and S powder. The hollow structure was achieved through the micelle-template-induced copolymerization of aniline and pyrrole monomer. Sulfuration was adopted to achieve dual-doping of $\mathrm{N}$ and $\mathrm{S}$. In addition, $\mathrm{ZnCl}_{2}$ salts as porogens were pivotal in the formation of the high-surface-area porous structure. Notably, hollow and porous structures with homogeneously effective N/S doping could be beneficial for $\mathrm{CO}_{2} \mathrm{RR}$ activity arising from the enhanced accessibility of active sites and mass transport of related species. Because of these favorable characteristics, SZ-HCN could exhibit excellent $\mathrm{CO}_{2} \mathrm{RR}$ activity and high CO Faradaic efficiency ( 93\%), outcompeting the catalysts for the competitive HER. Furthermore, SZ-HCN could maintain high efficiencies for at least $20 \mathrm{~h}$ durability tests. This simple strategy advances the development of efficient and robust carbon-based catalysts for a natural carbon cycle.

\section{Experimental}

\subsection{Chemicals}

All reagents were used without any further purification. Ultrapure water with a resistivity of $>18 \mathrm{M} \Omega \mathrm{cm}^{-1}$ was used in all experiments.

\subsection{Synthesis and preparation}

A total of $0.06 \mathrm{~g}$ Triton X-100 was dispersed in $60 \mathrm{ml}$ deionized water. Next, $0.4 \mathrm{~g}$ aniline and $0.3 \mathrm{~g}$ pyrrole were slowly dropped into this solution. After 30 min magnetic stirring and 30 min ultrasonication, a homogeneous solution was obtained. A precooled aqueous solution of $2.0 \mathrm{~g}$ ammonium persulfate (APS) and $2.0 \mathrm{~g} \mathrm{ZnCl}_{2}$ (volatile porogen) in $10 \mathrm{~mL} \mathrm{H}_{2} \mathrm{O}$ were added to the mixed solution in one portion. The polymerization reaction was carried out at $0-2{ }^{\circ} \mathrm{C}$ under a static condition for $12 \mathrm{~h}$. The obtained product was washed with ethanol and deionized water for several times and dried under vacuum at 60 ${ }^{\circ} \mathrm{C}$ for $24 \mathrm{~h}$, forming polyaniline-co-polypyrrole (PACP) hollow carbon nanospheres. At the same time, $\mathrm{ZnCl}_{2}$ diffuses onto PACP nanospheres (denoted PACP-Zn) at various positions. The as-prepared PACP-Zn (0.1 g) and $2.0 \mathrm{~g}$ of S powder were placed in a porcelain boat and calcined at $900^{\circ} \mathrm{C}$ under argon atmosphere for $2 \mathrm{~h}$. The obtained carbon material was denoted as SZ-HCN. For comparison, PACP nanospheres were synthesized by the polymerization of aniline and pyrrole without the addition of $\mathrm{ZnCl}_{2}$. Moreover, PACP solid nanospheres were synthesized by the polymerization of aniline and pyrrole without the addition of Triton X-100 as a reference. The CN (without Triton $\mathrm{X}-100, \mathrm{ZnCl}_{2}$, and sulfur), $\mathrm{HCN}$ (without $\mathrm{ZnCl}_{2}$ and sulfur), Z-HCN (without sulfur) and S-HCN (without $\mathrm{ZnCl}_{2}$ ) samples were directly calcined at $900{ }^{\circ} \mathrm{C}$ under argon atmosphere for $2 \mathrm{~h}$.

\subsection{Characterization}

The morphology and structure were characterized by field emission scanning electron microscopy (SEM, FEI JEOL-7800F) and transmission electron microscopy (TEM, JEM-2100F). A Raman spectrum was obtained by a Raman spectrometer (Rennishaw In Via) with a $514.5 \mathrm{~nm}$ laser excitation. X-ray photoelectron spectroscopy (XPS) was performed by an X-ray photoelectron spectrometer (Thermo VG Scientific ESCALAB 250, Thermo Electron, U.K.) with Al $K_{\alpha}$ X-ray radiation. The binding energies were calibrated on the basis of $\mathrm{C} 1 \mathrm{~s}$ peak $(284.8 \mathrm{eV})$. X-ray powder diffraction (XRD) patterns were acquired by an X-ray diffractometer (Rigaku Mini Flex 600) with $\mathrm{Cu} K_{\alpha}$ radiation $(\lambda=0.15418 \mathrm{~nm})$ in the range from $10^{\circ}$ to $80^{\circ}$. $\mathrm{N}_{2}$ adsorption/desorption isotherms were obtained by an ASAP 2460 system (Micromeritics) at $77 \mathrm{~K}$.

\subsection{Electrochemical measurements}

Electrochemical measurements were carried out on a three-electrode system with an electrochemical station (CHI $760 \mathrm{E}, \mathrm{CH}$ Instrument Inc). The $\mathrm{CO}_{2}$ electroreduction products were analyzed by gas chromatography (SRI 8610C). Electrolysis was performed in an H-type electrolytic cell with a Nafion®117 membrane as a separator. The three-electrode system includes a $\mathrm{Ag} / \mathrm{AgCl}$ electrode, platinum foil $\left(2 \mathrm{~cm}^{2}\right)$, and glass carbon electrode ( $3 \mathrm{~mm}$ ) as the reference, counter and working electrodes, respectively. Before electrolysis, $\mathrm{CO}_{2}$ (99.995\%) was bubbled in $0.1 \mathrm{M} \mathrm{KHCO}_{3}$ electrolyte for $30 \mathrm{~min}$. All potentials were converted to the reversible hydrogen electrode (RHE) on the basis of the Nernst equation:

$$
E_{\mathrm{RHE}}=E_{\mathrm{Ag} / \mathrm{AgCl}}+0.197+0.0591 \times \mathrm{pH}
$$

The total amount of $\mathrm{CO}$ produced was measured by gas 
chromatography (SRI 8610C). A GC run was initiated every 30 min. High purity Ar (99.999\%) was used as the carrier gas. The faradaic efficiencies of the gas products were calculated as follows:

$$
\mathrm{FE}=n F A \alpha v_{i} / j_{\text {total }}
$$

where $n=2$ is the number of electrons transferred per mole of CO, $F$ is the Faraday constant, $A$ is the integral area of the gas-phase products $\mathrm{CO}$ or $\mathrm{H}_{2}, \alpha$ is the conversion factor determined from the calibration of the GC with standard samples, $v_{\mathrm{i}}$ is the flow rate of $\mathrm{CO}_{2}$, and $j_{\text {total }}$ is the total current at each applied potential.

\subsection{Calculations}

The density functional theory (DFT) calculations were performed using the VASP package of Perdew-Burke-Ernzerhof $[51,52]$. The structures were relaxed until the residual force on each atom was less than $0.01 \mathrm{eV}^{-1}$. The energy cutoff of plane wave functions was set to $500 \mathrm{eV}$. Moreover, 14 Å vacuum layers were used. The reciprocal space was sampled using a $3 \times 3$ $\times 1$ point grid by the Monkhorst-Pack K-points scheme. A $10 \times$ $10 \times 1$ graphene supercell was used. The adsorption energy was calculated according to the following formula:

$$
E_{\mathrm{a}}=E_{\text {final }}-E_{\text {substrate }}-E_{\text {adsorbate }}
$$

where $E_{\mathrm{a}}$ is the adsorption energy of the adsorbed $\mathrm{COOH}^{*}$ and $\mathrm{CO}^{*}, E_{\text {final }}$ is the total energy of the adsorbed substance on the substrate, $E_{\text {substrate }}$ is the total energy of the substrate, and $E_{\text {adsorbate }}$ is the total energy of the adsorbate.

Based on the calculated hydrogen electrode (CHE) model, the free energy diagram was calculated at 0 VRHE. The Gibbs free energy $(\Delta G)$ could be expressed as follows:

$$
\Delta G=E_{\mathrm{a}}+\Delta \mathrm{ZPE}-T \Delta S
$$

where $\triangle \mathrm{ZPE}$ and $T \Delta S$ are the zero-point energy correction and entropic energy, respectively.

\section{Results and discussion}

\subsection{Physical characterization}

N/S dual-doped high-surface-area hollow carbon nanospheres were synthesized by a facile approach, which is schematically depicted in Scheme 1. PACP-Zn was fabricated by the polymerization of aniline and pyrrole at the interface of Triton $\mathrm{X}-100$ micelles in the presence of $\mathrm{ZnCl}_{2}$ salt and hydrophilic oxidant APS [53]. $\mathrm{ZnCl}_{2}$ diffused onto the PACP nanospheres at various positions, which had no discernible effect on polymeri-

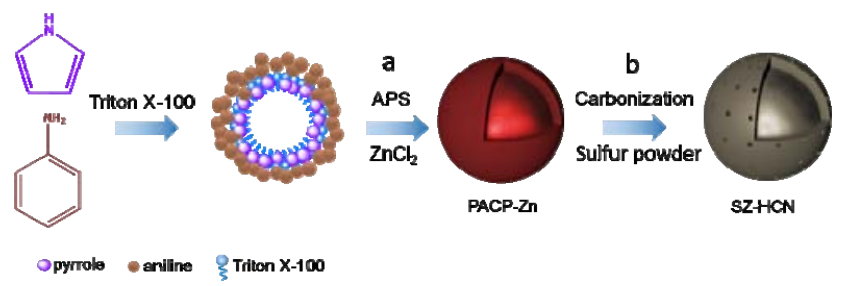

Scheme 1. Schematic illustration of the synthesis process of SZ-HCN. (a Polymerization of pyrrole and aniline; (b) Pyrolysis is synchronous with sulfuration at $900^{\circ} \mathrm{C}$. zation. Moreover, the as-prepared PACP-Zn and S powder were placed in a porcelain boat for heat treatment at $900{ }^{\circ} \mathrm{C}$ for $2 \mathrm{~h}$ to yield the target N/S dual-doped product (SZ-HCN). Notably, $\mathrm{ZnCl}_{2}$ salts were volatilized during calcination, leading to the formation of abundant pores, and in turn, a porous structure.

SEM and TEM images remarkably showed well-defined nanospheres of the samples (Figs. 1 and S1), which demonstrated that the total diameter of the nanospheres ranged from 70 to $120 \mathrm{~nm}$. TEM images (Fig. 1(c) and 1(d)) display the hollow structure of SZ-HCN, having the inner diameter ranging from 40 to $60 \mathrm{~nm}$. This hollow structure may provide high SSA and favorable channels for transportation and penetration of the electrolyte and related $\mathrm{CO}_{2} \mathrm{RR}$ species. Comparison of reference catalysts (Figs. 1 and S2) confirms that $\mathrm{ZnCl}_{2}$ salts serve as a sacrificial template and enable the formation of the nanoporous structure without destroying the hollow structure. In Figs. S2(a) and S2(b), the SEM and TEM images showed that the $\mathrm{CN}$ sample was a solid nanosphere without a hollow structure and different diameters, revealing that Triton X-100 as the micelle template assisted the formation of the hollow structure. The HAADF-STEM (Fig. 1(c)) and corresponding EDS images (Fig. 1(d)-(g)) of SZ-HCN revealed that N and S species were uniformly distribute on the carbon matrix, confirming the successful introduction of $\mathrm{N}$ and $\mathrm{S}$ atoms.

Fig. 2(a) shows the XRD patterns of the carbon samples, exhibiting two broad peaks at approximately $2 \theta=25^{\circ}$ and $44^{\circ}$. The peaks were characteristic of (002) and (101) planes (JCPDS no. 34-0567), demonstrating that the samples possessed a strong graphitic structure $[54,55]$. There were no diffraction peaks of crystalline $\mathrm{Zn}$ or $\mathrm{Zn}$ compounds. The Raman spectrum (Fig. 2(b)) indicated two distinctive peaks at 1340 and 1575 $\mathrm{cm}^{-1}$, corresponding to the $\mathrm{D}$ and $\mathrm{G}$ bands, respectively. The $\mathrm{D}$ band was attributed to the defective/disordered carbon and $G$ band to the graphitic $s p^{2}$-carbon [56,57]. Nitrogen

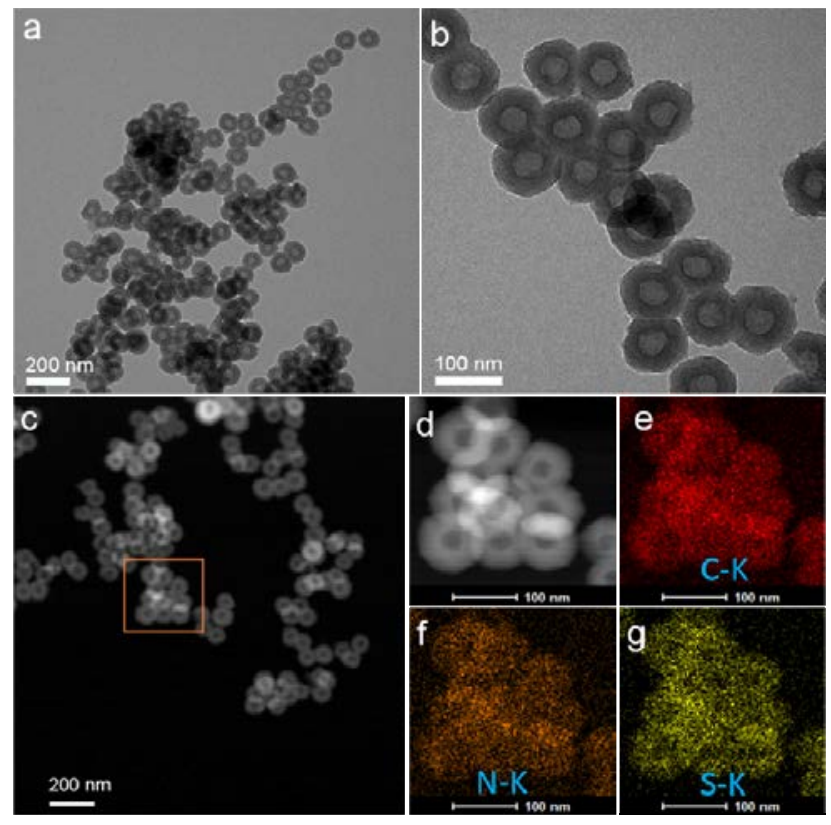

Fig. 1. TEM images of (a, b) SZ-HCN. (c) HAADF image and (d-g) elemental mapping of SZ-HCN. 
(a)
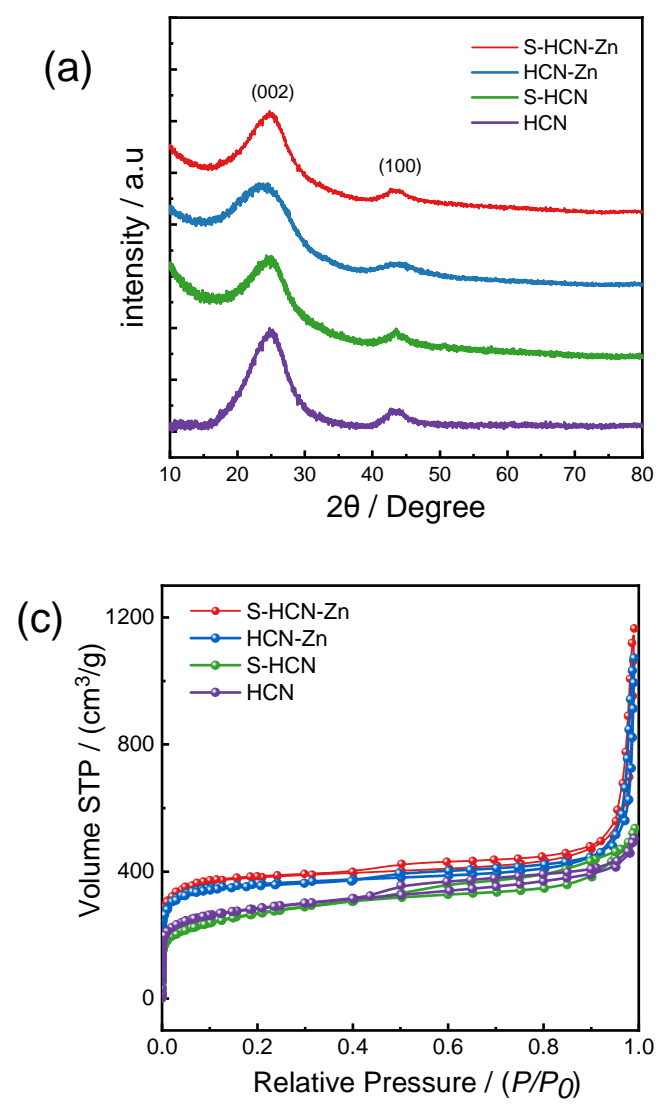
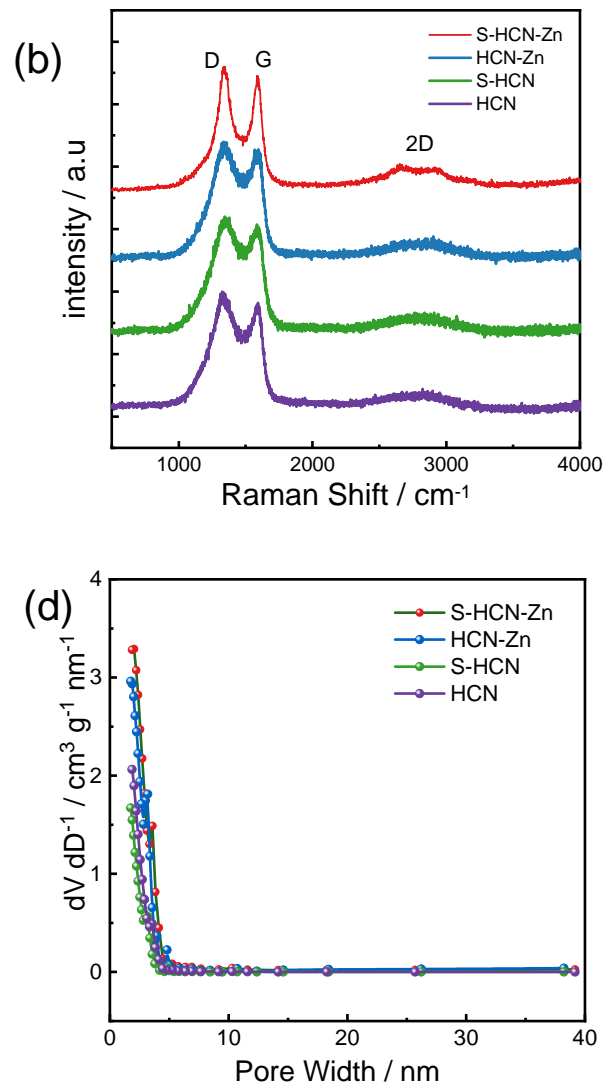

Fig. 2. (a) XRD patterns; (b) Raman spectrum; (c) $\mathrm{N}_{2}$ adsorption isotherms; (d) Pore size distributions.

adsorption-desorption curves were categorized as type-IV isotherms with pronounced H4 hysteresis loops (Fig. 2(c)), revealing the existence of mesoporous and microporous structures. The BET specific surface areas were evaluated on the basis of the Brunauer-Emmett-Teller (BET) model. The specific surface areas of SZ-HCN $\left(1510 \mathrm{~m}^{2} \mathrm{~g}^{-1}\right)$ and Z-HCN $\left(1390 \mathrm{~m}^{2}\right.$ $\left.\mathrm{g}^{-1}\right)$ were remarkably higher than those of S-HCN $\left(815 \mathrm{~m}^{2} \mathrm{~g}^{-1}\right)$ and HCN $\left(790 \mathrm{~m}^{2} \mathrm{~g}^{-1}\right)$, which could be attributed to the addition of $\mathrm{ZnCl}_{2}$ salts. Moreover, the pore size distribution curves (Fig. 2(d)) were evaluated in the range of 1-10 nm, exhibiting the coexistence of microporous and mesoporous structures. It is well known that highly porous structures could provide abundant three phase interfaces for convenient mass transport and accessibility of the related $\mathrm{CO}_{2} \mathrm{RR}$ species [58].

The survey XPS spectra of SZ-HCN (Fig. 3(a)) showed the presence of $\mathrm{C}, \mathrm{O}, \mathrm{N}$, and $\mathrm{S}$, which is in agreement with EDS results. The high-resolution C $1 s$ XPS spectrum of SZ-HCN (Fig. 3 (b)) revealed different peaks including those for $\mathrm{C}=\mathrm{C}(284.8$ $\mathrm{eV}), \mathrm{C}=\mathrm{N}(285.4 \mathrm{eV}), \mathrm{C}-\mathrm{O}(286.2 \mathrm{eV}), \mathrm{C}-\mathrm{N}(287.1 \mathrm{eV})$, and $\mathrm{C}=\mathrm{O} / \mathrm{O}-\mathrm{C}=\mathrm{O}(289.1 \mathrm{eV}$ ) [59]. The $\mathrm{N} 1 s$ spectrum (Fig. 3(c)) could be resolved into four peaks centered at 398.4, 399.6, 401.0, and $402.7 \mathrm{eV}$, which were assigned respectively to pyridinic-N, pyrrolic- $\mathrm{N}$, graphitic- $\mathrm{N}$, and oxidized nitrogen [60]. Figs. 3(a) and 3(b) suggested that $\mathrm{N}$ atoms were successfully doped. Notably, pyridinic- $\mathrm{N}$ with a negative charge as active sites has the potential to adsorb $\mathrm{CO}_{2}$ molecules for facilitating $\mathrm{CO}_{2} \mathrm{RR}$ [61-63]. The S $2 p$ XPS spectrum (Fig. 3(d)) was deconvoluted into three peaks at $163.8,165.1$, and $168.5 \mathrm{eV}$, corre- sponding to $\mathrm{C}-\mathrm{S}\left(2 p_{3 / 2}\right), \mathrm{C}-\mathrm{S}-\mathrm{C}\left(2 p_{1 / 2}\right)$ and $\mathrm{C}-\mathrm{SO}_{x}-\mathrm{C}$, respectively. The success of dual doping can be attributed to the synergistic effect of $\mathrm{S}$ and $\mathrm{N}$, which could enhance the $\mathrm{CO}_{2} \mathrm{RR}$ activity because of the modification of the interactions between the C and $\mathrm{S}$ and $\mathrm{N}$ atoms $[29,48,64]$.

\subsection{Electrochemical measurements}

To evaluate the electrochemical $\mathrm{CO}_{2}$ reduction reaction activity, experiments using a three-electrode system were carried out in $\mathrm{N}_{2}$ - and $\mathrm{CO}_{2}$-saturated $0.1 \mathrm{M} \mathrm{KHCO}_{3}$ electrolyte. The $\mathrm{CO}_{2} \mathrm{RR}$ activity of SZ-HCN was first evaluated based on linear sweep voltammetry (LSV) polarization curves (Fig. 4(a)). When the potential was swept in the range from 0 to $-1.2 \mathrm{~V}$ versus RHE, only $\mathrm{CO}$ and $\mathrm{H}_{2}$ were detected in the final products by an on-line gas chromatograph. SZ-HCN exhibited higher reductive currents under $\mathrm{a} \mathrm{CO}_{2}$ atmosphere than under a $\mathrm{N}_{2}$ atmosphere, manifesting the suppressed HER activity on SZ-HCN by $\mathrm{CO}_{2} \mathrm{RR}$. Fig. 4(b) shows that SZ-HCN has the lowest onset potential of $-0.40 \mathrm{~V}$ and the highest current density, indicating its highest $\mathrm{CO}_{2} \mathrm{RR}$ activity among all samples. Quantification of the $\mathrm{CO}_{2} \mathrm{RR}$ activity and selectivity was performed by the controlled-potential bulk electrolysis method. As seen in Fig. 4(c), the Faradaic efficiency (FE) for CO toward SZ-HCN gradually increased from -0.30 to $-0.60 \mathrm{~V}$ and reached the maximum value $(93 \%)$ at $-0.60 \mathrm{~V}$. Meanwhile, the competitive HER was suppressed with the $\mathrm{FE}$ of $\mathrm{H}_{2}$ being than $10 \%$ (Fig. S4(a)). At low potentials, the CO FE of SZ-HCN decreased because the 


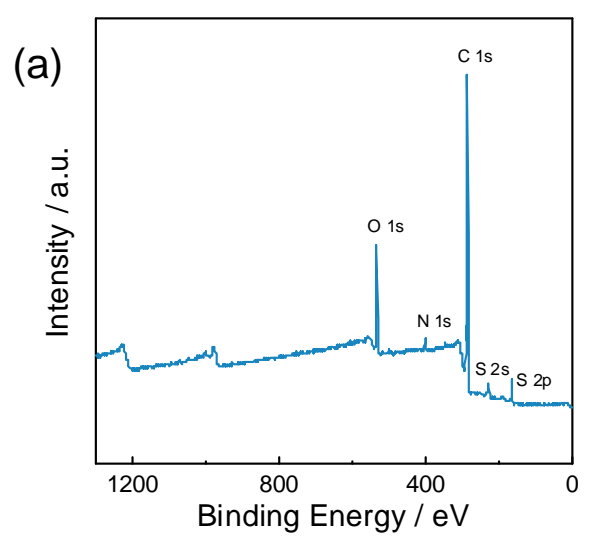

(b)
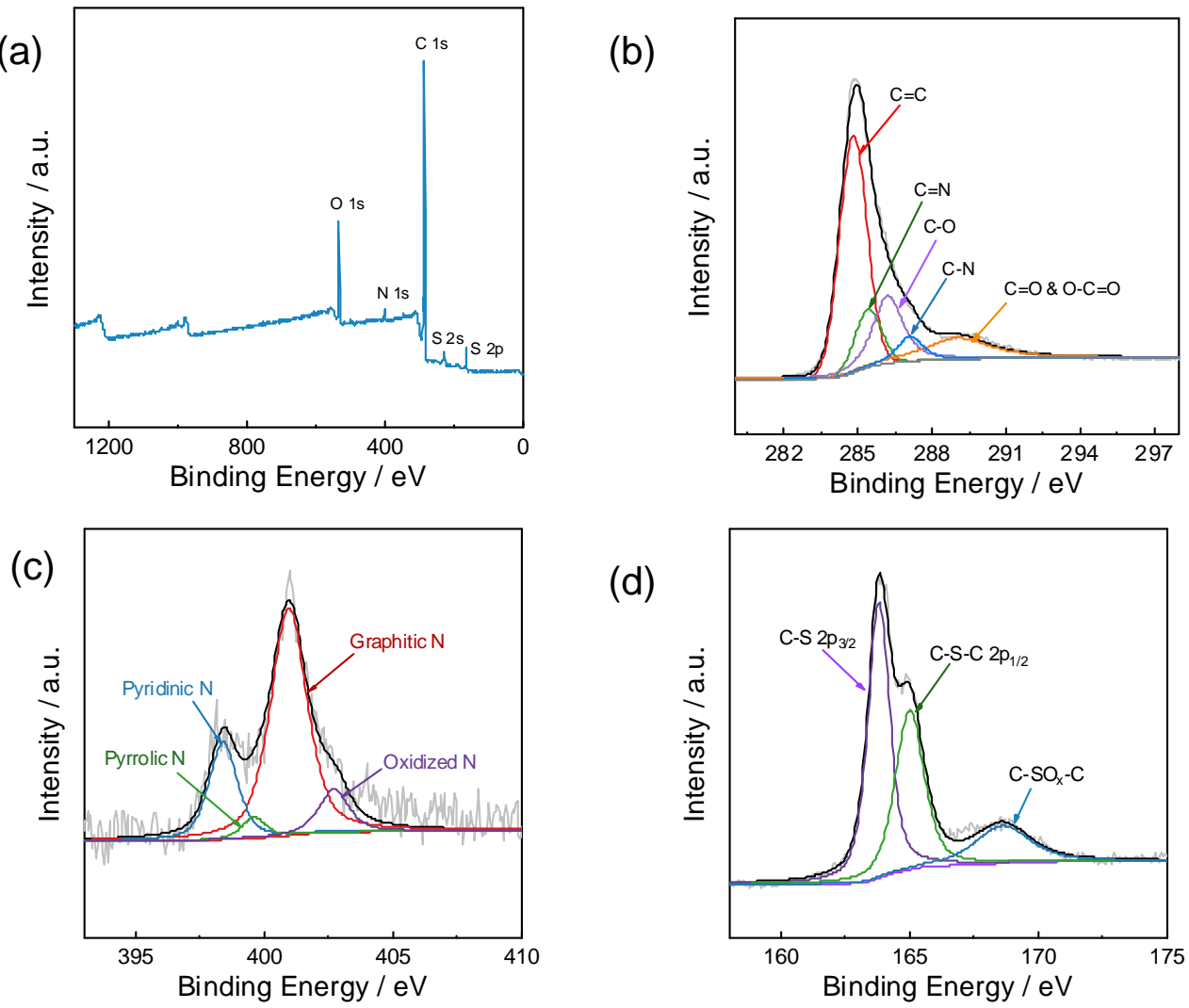

(d)

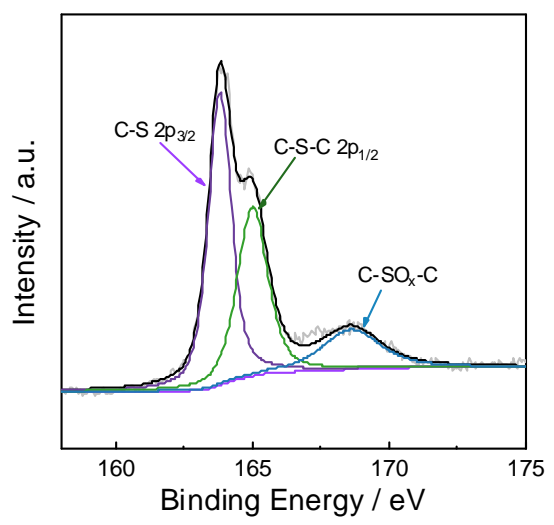

Fig. 3. (a) Survey XPS spectra; high-resolution C $1 s$ (b), N $1 s$ (c) and S $2 p$ (d) XPS spectra of SZ-HCN.

competitive HER was dominant. Additionally, SZ-HCN achieved the maximum CO FE (93\%) among those for Z-HCN (84\%), S-HCN (40\%), and HCN (21\%). Through a comparison of the CRR performance of Z-HCN and HCN, it was found that a high SSA and nanoporous structures formed by the volatilization of $\mathrm{ZnCl}_{2}$ salts facilitate the exposure of more active sites and lead to enhanced activity for the $\mathrm{CO}_{2} \mathrm{RR}$. In Fig. S3, CN catalysts demonstrated a lower current density and a more negative onset potential than those of HCN, probably because the solid nanospheres without a hollow structure provided less three phase interfaces, which is inconvenient for mass transport and results in poor accessibility of the related $\mathrm{CO}_{2} \mathrm{RR}$ species. In addition, electrochemical active surface area (ECSA) analysis was carried out based on electrochemical double-layer capacitance ( $\mathrm{C}_{d l}$ ) (Figs. S4(b) and S5) [65]. The $\mathrm{C}_{d l}$ values of SZ-HCN, Z-HCN, S-HCN, and HCN were calculated as 26.81, 24.55, 16.56, and $16.03 \mathrm{mF} \mathrm{cm}^{-2}$, respectively. $\mathrm{C}_{d l}$ of Z-HCN was larger than that of $\mathrm{HCN}$, also suggesting that Z-HCN had more exposed catalytic active sites for electrolysis during the $\mathrm{CO}_{2} \mathrm{RR}$. Although there was no significant difference in $\mathrm{C}_{d l}$ between SZ-HCN and $\mathrm{Z}-\mathrm{HCN}$, the $\mathrm{CO}_{2} \mathrm{RR}$ performance of SZ-HCN was superior to that of Z-HCN, which demonstrated the dual doping of $\mathrm{N}$ and $\mathrm{S}$ atoms improved the activity of the active sites to a greater extent than that in the case of $\mathrm{N}$ doping alone. Tafel analysis was carried out to determine the kinetics of the $\mathrm{CO}_{2} \mathrm{RR}$ on different catalysts. In Fig. 4(d), the measured Tafel slope of SZ-HCN $(122$ $\mathrm{mV} \mathrm{dec}^{-1}$ ) was close to $118 \mathrm{mV} \mathrm{dec}^{-1}$, revealing that sin- gle-electron transfer of $\mathrm{CO}_{2}$ to form $\mathrm{COOH}^{*}$ was the rate-determining step [66]. In comparison, the Tafel slope for SZ-HCN was smaller than that of other catalysts, which demonstrated the favorable kinetics for the formation of CO. The stability of the $\mathrm{CO}_{2} \mathrm{RR}$ was further investigated by long-time durability measurements. As illustrated in Fig. 4(e), SZ-HCN, Z-HCN, S-HCN, and HCN were acquired by the potentiostatic method at a constant voltage of $-0.60 \mathrm{~V}$ for $20 \mathrm{~h}$, which indicated their excellent durability. After each $2 \mathrm{~h}$ interval, the outlet gases were collected and analyzed by GC, and the corresponding CO FE was calculated. The SZ-HCN catalyst still presented a stable current density of $-5.2 \mathrm{~mA} \mathrm{~cm}-2$, with a high CO FE for $20 \mathrm{~h}$ (Fig. 4(f)), which revealed its remarkable long-term stability during electrochemical operation.

\subsection{DFT calculations}

To further probe the impact of $\mathrm{N}$ and $\mathrm{S}$ dual doping on the mechanism underlying the $\mathrm{CO}_{2}$-to-CO reduction, DFT calculations were carried out. Based on previous studies, the electron-withdrawing nitrogen with a similar size as the $\mathrm{C}$ atom but larger electronegativity $(\chi=3.04)$ can be efficiently doped into carbon, which alters the charge polarization and asymmetrical electron spin density. The pyridinic nitrogen with a lone pair as a Lewis basic site has widely been considered as the active site for enhanced $\mathrm{CO}_{2}$ adsorption, $\mathrm{COOH}^{*}$ formation, and $\mathrm{CO}^{*}$ desorption in $\mathrm{CO}_{2}$-to- $\mathrm{CO}$ reduction [61-63,67-69]. As per the 

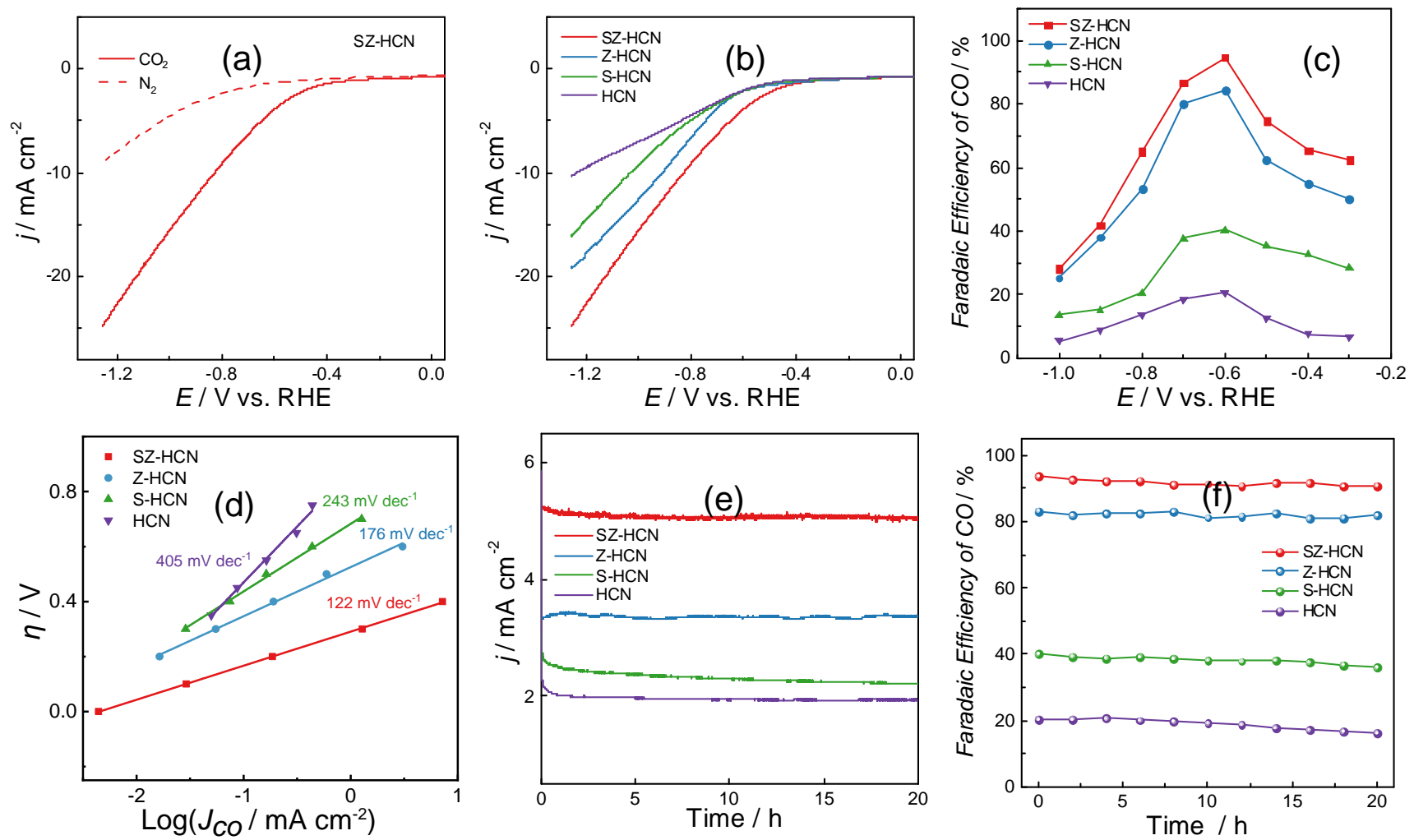

Fig. 4. (a) LSV curves of SZ-HCN in $\mathrm{CO}_{2}$-saturated and $\mathrm{N}_{2}$-saturated $0.1 \mathrm{M} \mathrm{KHCO}_{3}$ solution; (b) $\mathrm{LSV}$ curves in $\mathrm{CO}_{2}$-saturated solution, in the presence of various electrocatalysts; (c) Faradaic efficiencies of $\mathrm{CO}$ by capitalizing on various cathodes at potentials ranging from -0.30 to $-1.0 \mathrm{~V}$ versus RHE; (d) Tafel plots of different samples; (e) Chronoamperometric curves of stability test and (f) stability of faradaic efficiency for $\mathrm{CO}_{2}$ reduction at $-0.60 \mathrm{~V}$ in the $\mathrm{CO}_{2}$-saturated $0.1 \mathrm{M} \mathrm{KHCO}_{3}$ solution.

periodic table of elements, $\mathrm{S}$ has a larger atomic size than $\mathrm{C}$ but similar electronegativity $(\chi=2.58$ and 2.55 , respectively), which results in high spin densities within the surrounding $C$ atoms [70]. S doping can modify the electronic interactions on the $\mathrm{C}$ atoms and thus enhance the catalytic activity [71]. We proposes a possible reaction mechanism $\left(\mathrm{CO}_{2}+2 \mathrm{H}^{+}+2 \mathrm{e}^{-} \rightarrow \mathrm{CO}\right.$ $+\mathrm{H}_{2} \mathrm{O}$ ) involving two consecutive proton-electron coupling reactions and two intermediates $\left(\mathrm{COOH}^{*}\right.$ and $\left.\mathrm{CO}^{*}\right)$, as illustrated in Fig. 5(a) [72]. On the basis of the $\mathrm{CO}_{2}$-to-CO reaction pathway, the free energy diagram was calculated (Fig. 5(b)). Both SZ-HCN and Z-HCN had a large Gibbs free energy change $(\Delta G)$ for the formation of $\mathrm{COOH}^{*}$, which revealed that the first proton-coupled electron transfer was the rate-determining step. The calculation results in Fig. 5(b) show that $\Delta G$ for $\mathrm{COOH}^{*}$ adsorption on the pyridinic $\mathrm{N}$ adjacent to the C-bonded $\mathrm{S}$ was lower than that for the pure pyridinic $\mathrm{N}$, indicating that Z-HCN must overcome a higher reaction energy barrier to form $\mathrm{COOH}^{*}$. This result was also in agreement with the results of Tafel analysis and the $\mathrm{CO}_{2} \mathrm{RR}$ activities of SZ-HCN and Z-HCN. Controlled experiments and theoretical results led us to conclude that the dual doping of $\mathrm{N}$ and $\mathrm{S}$ could improve the $\mathrm{CO}_{2} \mathrm{RR}$ performance. The difference between SZ-HCN and Z-HCN was ascribed to the additional incorporation of S, which induced a significant electron spin density redistribution.
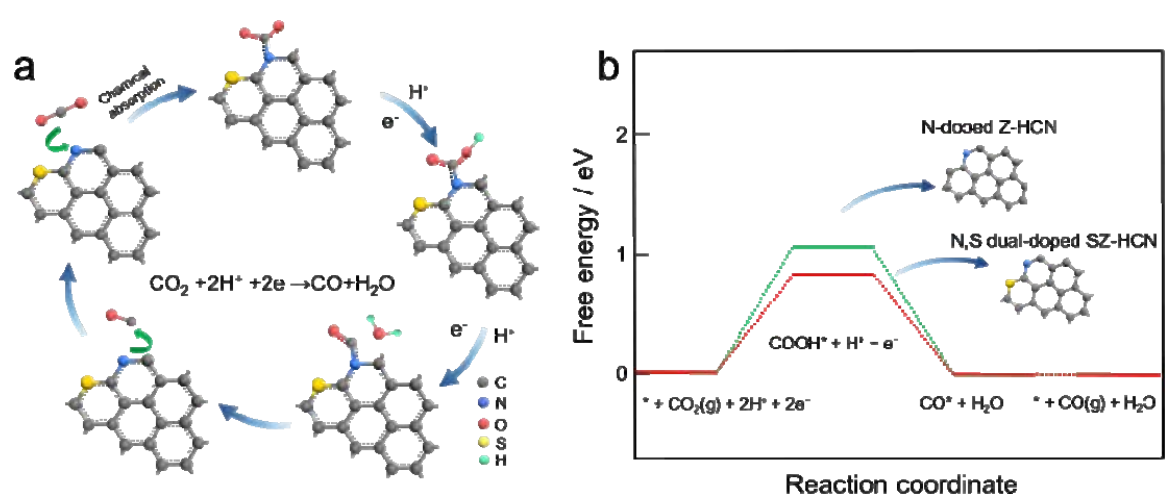

Fig. 5. (a) Proposed mechanism for the nitrogen-doped catalytic site. (b) Calculated free energy diagram of $\mathrm{CO}_{2}$ reduction to $\mathrm{CO}$ on $\mathrm{N}$-doped Z-HCN and N,S dual-doped gSZ-HCN. 


\section{Conclusions}

In summary, we have prepared N/S dual-doped hollow carbon materials by a simple micelle template-induced method and pyrolysis. Hollow and porous structures with a high SSA not only offered adequate electrolyte/electrode contact area but also provided abundant channels for faster transportation of the $\mathrm{CO}_{2} \mathrm{RR}$-related species. DFT calculations revealed that the additional S doping could offer more active sites, thus decreasing the $\Delta \mathrm{G}$ value for the formation of the $\mathrm{COOH}^{*}$ intermediate toward the electrocatalytic reduction of $\mathrm{CO}_{2}$ to $\mathrm{CO}$. The SZ-HCN catalyst showed high activity and selectivity for $\mathrm{CO}_{2}$-to-CO reduction along with good long-term stability; the CO Faradaic efficiency was as high as $\sim 93 \%$ at a low potential of $-0.60 \mathrm{~V}$. Our work provides a robust porous carbon electrocatalyst with heteroatom doping for efficient and selective $\mathrm{CO}_{2}$ reduction, which has the potential to replace expensive noble metal catalysts.

\section{References}

[1] P. De Luna, C. Hahn, D. Higgins, S. A. Jaffer, T. F. Jaramillo, E. H. Sargent, Science, 2019, 364, eaav3506.

[2] J. Hao, W. Shi, Chin. J. Catal., 2018, 39, 1157-1166.

[3] Y. F. Wang, P. Han, X. M. Lv, L. J. Zhang, G. F. Zheng, Joule, 2018, 2, 2551-2582.

[4] Z. Gu, H. Shen, L. Shang, X. Lv, L. Qian, G. Zheng, Small Methods, 2018, 2, 1800121.

[5] C. Yan, L. Lin, G. Wang, X. Bao, Chin. J. Catal., 2019, 40, 23-37.

[6] Z. Sun, T. Ma, H. Tao, Q. Fan, B. Han, Chem, 2017, 3, 560-587.

[7] E. R. Cave, C. Shi, K. P. Kuhl, T. Hatsukade, D. N. Abram, C. Hahn, K. Chan, T. F. Jaramillo, ACS Catal., 2018, 8, 3035-3040.
[8] J. Rosen, G. S. Hutchings, Q. Lu, S. Rivera, Y. Zhou, D. G. Vlachos, F. Jiao, ACS Catal., 2015, 5, 4293-4299.

[9] S. Narayanaru, J. Chinnaiah, K. L. Phani, F. Scholz, Electrochim. Acta, 2018, 264, 269-274.

[10] W. Zhu, L. Zhang, P. Yang, C. Hu, Z. Luo, X. Chang, Z. J. Zhao, J. Gong, Angew. Chem. Int. Ed., 2018, 57, 11544-11548.

[11] H. P. Yang, Q. Lin, H. W. Zhang, G. D. Li, L. D. Fan, X. Y. Chai, Q. L. Zhang, J. H. Liu, C. X. He, Chem. Commun., 2018, 54, 4108-4111.

[12] W. Zhan, J. Wang, H. Wang, J. Zhang, X. Liu, P. Zhang, M. Chi, Y. Guo, Y. Guo, G. Lu, S. Sun, S. Dai, H. Zhu, J. Am. Chem. Soc., 2017, 139, 8846-8854.

[13] X. Bai, W. Chen, C. Zhao, S. Li, Y. Song, R. Ge, W. Wei, Y. Sun, Angew. Chem. Int. Ed., 2017, 56, 12219-12223.

[14] M. Ma, H. A. Hansen, M. Valenti, Z. Wang, A. Cao, M. Dong, W. A. Smith, Nano Energy, 2017, 42, 51-57.

[15] Z. Chen, K. Mou, X. Wang, L. Liu, Angew. Chem. Int. Ed., 2018, 57, 12790-12794.

[16] Y. Yiliguma, Z. Wang, C. Yang, A. Guan, L. Shang, A. M. Al-Enizi, L. Zhang, G. Zheng, J. Mater. Chem. A, 2018, 6, 20121-20127.

[17] L. Liu, N. Tian, L. Huang, Y.-H. Hong, A.-Y. Xie, F.-Y. Zhang, C. Xiao, Z.-Y. Zhou, S.-G. Sun, Chin. J. Catal., 2016, 37, 1070-1075.

[18] P. Kang, C. Cheng, Z. Chen, C. K. Schauer, T. J. Meyer, M. Brookhart, J. Am. Chem. Soc., 2012, 134, 5500-5503.

[19] Z. Cao, J. S. Derrick, J. Xu, R. Gao, M. Gong, E. M. Nichols, P. T. Smith, X. Liu, X. Wen, C. Coperet, C. J. Chang, Angew. Chem. Int. Ed., 2018, $57,4981-4985$.

[20] B. M. Szyja, ChemElectroChem, 2018, 5, 2105-2112.

[21] G. Yang, Z. Yu, J. Zhang, Z. Liang, Chin. J. Catal., 2018, 39, 914-919.

[22] Y. Zhou, F. Che, M. Liu, C. Zou, Z. Liang, P. De Luna, H. Yuan, J. Li, Z. Wang, H. Xie, H. Li, P. Chen, E. Bladt, R. Quintero-Bermudez, T.-K. Sham, S. Bals, J. Hofkens, D. Sinton, G. Chen, E. H. Sargent, Nat. Chem., 2018, 10, 974-980.

[23] Q. Lu, F. Jiao, Nano Energy, 2016, 29, 439-456.

[24] D. J. Wilhelm, D. R. Simbeck, A.D. Karp, R. L. Dickenson, Fuel Pro-

\section{Graphical Abstract}

Chin. J. Catal., 2020, 41: 830-838 doi: S1872-2067(19)63485-6

\section{Nitrogen and sulfur dual-doped high-surface-area hollow carbon nanospheres for efficient $\mathrm{CO}_{2}$ reduction}

Guodong Li, Yongjie Qin, Yu Wu, Lei Pei, Qi Hu, Hengpan Yang, Qianling Zhang, Jianhong Liu, Chuanxin He* University of Science and Technology of China; Shenzhen University
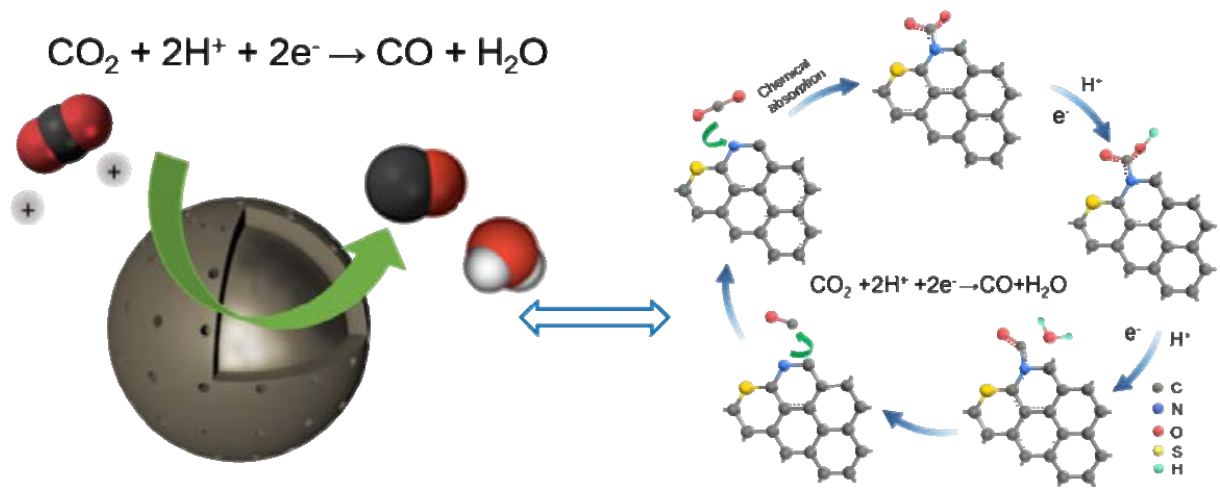

A N and S dual-doped carbon-based catalyst with a high specific surface area was prepared via a facile route, which showed remarkably high activity and selectivity for $\mathrm{CO}_{2}$-to-CO electroreduction, along with excellent stability. 
cess. Technol., 2001, 7, 139-148.

[25] Q. Lu, J. Rosen, Y. Zhou, G. S. Hutchings, Y. C. Kimmel, J. G. Chen, F. Jiao, Nat. Commun., 2014, 5, 3242.

[26] W. Zhu, Y. J. Zhang, H. Zhang, H. Lv, Q. Li, R. Michalsky, A. A. Peterson, S. Sun, J. Am. Chem. Soc., 2014, 136, 16132-16135.

[27] R.-H. Guo, C.-F. Liu, T.-C. Wei, C.-C. Hu, Electrochem. Commun., 2017, 80, 24-28.

[28] Y. S. Ham, S. Choe, M. J. Kim, T. Lim, S.-K. Kim, J. J. Kim, Appl. Catal. $B, 2017,208,35-43$.

[29] X. Duan, J. Xu, Z. Wei, J. Ma, S. Guo, S. Wang, H. Liu, S. Dou, Adv. Mater., 2017, 29, 1701784.

[30] J. Xie, X. Zhao, M. Wu, Q. Li, Y. Wang, J. Yao, Angew. Chem. Int. Ed., 2018, 57, 9640-9644.

[31] M. A. Ghausi, J. Xie, Q. Li, X. Wang, R. Yang, M. Wu, Y. Wang, L. Dai, Angew. Chem. Int. Ed., 2018, 57, 13135-13139.

[32] J. Wu, R. M. Yadav, M. Liu, P. P. Sharma, C. S. Tiwary, L. Ma, X. Zou, X. D. Zhou, B. I. Yakobson, J. Lou, P. M. Ajayan, ACS Nano, 2015, 9, 5364-5371.

[33] Y. Liu, S. Chen, X. Quan, H. Yu, J. Am. Chem. Soc., 2015, 137, 11631-11636.

[34] Y. Zhao, J. J. Liang, C. Y. Wang, J. M. Ma, G. G. Wallace, Adv. Energy. Mater., 2018, 8, 1702524.

[35] P. Han, X. Yu, D. Yuan, M. Kuang, Y. Wang, A. M. Al-Enizi, G. Zheng, J. Colloid Interface Sci., 2019, 534, 332-337.

[36] Y. Song, W. Chen, C. Zhao, S. Li, W. Wei, Y. Sun, Angew. Chem. Int. Ed., 2017, 56, 10840-10844.

[37] X. Sun, L. Lu, Q. Zhu, C. Wu, D. Yang, C. Chen, B. Han, Angew. Chem. Int. Ed., 2018, 57, 2427-2431.

[38] F. Li, M. Xue, G. P. Knowles, L. Chen, D. R. MacFarlane, J. Zhang, Electrochim. Acta, 2017, 245, 561-568.

[39] H. Wang, J. Jia, P. Song, Q. Wang, D. Li, S. Min, C. Qian, L. Wang, Y. F. Li, C. Ma, T. Wu, J. Yuan, M. Antonietti, G. A. Ozin, Angew. Chem. Int. Ed., 2017, 56, 7847-7852.

[40] N. P. Wickramaratne, J. Xu, M. Wang, L. Zhu, L. Dai, M. Jaroniec, Chem. Mater, 2014, 26, 2820-2828.

[41] Y. Pan, R. Lin, Y. Chen, S. Liu, W. Zhu, X. Cao, W. Chen, K. Wu, W. C. Cheong, Y. Wang, L. Zheng, J. Luo, Y. Lin, Y. Liu, C. Liu, J. Li, Q. Lu, X. Chen, D. Wang, Q. Peng, C. Chen, Y. Li, J. Am. Chem. Soc., 2018, 140, 4218-4221.

[42] A. Kong, X. Zhu, Z. Han, Y. Yu, Y. Zhang, B. Dong, Y. Shan, ACS Catal, 2014, 4, 1793-1800.

[43] Y. Chang, F. Hong, J. Liu, M. Xie, Q. Zhang, C. He, H. Niu, J. Liu, Carbon, 2015, 87, 424-433.

[44] G. A. Ferrero, K. Preuss, A. Marinovic, A. B. Jorge, N. Mansor, D. J. Brett, A. B. Fuertes, M. Sevilla, M. M. Titirici, ACS Nano, 2016, 10, 5922-5932.

[45] J. Liang, Y. Jiao, M. Jaroniec, S. Z. Qiao, Angew. Chem. Int. Ed., 2012, 51, 11496-11500.

[46] R. Li, Z. Wei, X. Gou, ACS Catal., 2015, 5, 4133-4142.

[47] J. Wang, J. Hao, D. Liu, S. Qin, D. Portehault, Y. Li, Y. Chen, W. Lei, ACS Energy Lett., 2017, 2, 306-312.
[48] H. Yang, Y. Wu, Q. Lin, L. Fan, X. Chai, Q. Zhang, J. Liu, C. He, Z. Lin, Angew. Chem. Int. Ed., 2018, 57, 15476-15480.

[49] G. Li, L. Pei, Y. Wu, B. Zhu, Q. Hu, H. Yang, Q. Zhang, J. Liu, C. He, J. Mater. Chem. A, 2019, 7, 11223-11233.

[50] G. Han, Y. H. Jin, R. A. Burgess, N. E. Dickenson, X. M. Cao, Y. Sun, J. Am. Chem. Soc., 2017, 139, 15584-15587.

[51] J. P. Perdew, J. A. Chevary, S. H. Vosko, K. A. Jackson, M. R. Pederson, D. J. Singh, C. Fiolhais, Phys. Rev. B, 1992, 46, 6671-6687.

[52] G. Kresse,J. Furthmuller, Comp. Mater. Sci., 1996, 6, 15-50.

[53] C. Zhou, J. Han, G. Song, R. Guo, J. Polym. Sci., Part A, 2008, 46, 3563-3572.

[54] Y. Li, H. Zhang, Y. Wang, P. Liu, H. Yang, X. Yao, D. Wang, Z. Tang, H. Zhao, Energy Environ. Sci., 2014, 7, 3720-3726.

[55] J. Li, Y. J. Song, G. X. Zhang, H. Y. Liu, Y. R. Wang, S. H. Sun, X. W. Guo, Adv. Funct. Mater., 2017, 27, 1604356.

[56] F. Tuinstra, J. L. Koenig, J. Chem. Phys., 1970, 53, 1126.

[57] R. J. Nemanich,S. A. Solin, Phys. Rev. B, 1979, 20, 392-401.

[58] C. Tang, H. F. Wang, Q. Zhang, Acc. Chem. Res., 2018, 51, 881-889.

[59] J. Yang, H. Sun, H. Liang, H. Ji, L. Song, C. Gao, H. Xu, Adv. Mater., 2016, 28, 4606-4613.

[60] Y. Zhao, R. Nakamura, K. Kamiya, S. Nakanishi, K. Hashimoto, Nat. Commun., 2013, 4, 2390.

[61] P. P. Sharma, J. Wu, R. M. Yadav, M. Liu, C. J. Wright, C. S. Tiwary, B. I. Yakobson, J. Lou, P. M. Ajayan, X. D. Zhou, Angew. Chem. Int. Ed., 2015, 54, 13701-13705.

[62] J. Wu, M. Liu, P. P. Sharma, R. M. Yadav, L. Ma, Y. Yang, X. Zou, X. D. Zhou, R. Vajtai, B. I. Yakobson, J. Lou, P. M. Ajayan, Nano Lett., 2016, 16, 466-470.

[63] S. Liu, H. B. Yang, X. Huang, L. H. Liu, W. Z. Cai, J. J. Gao, X. N. Li, T. Zhang, Y. Q. Huang, B. Liu, Adv. Funct. Mater., 2018, 28, 1800499.

[64] W. Li, M. Seredych, E. Rodriguez-Castellon, T. J. Bandosz, ChemSusChem, 2016, 9, 606-616.

[65] H. P. Yang, H. W. Zhang, Y. Wu, L. D. Fan, X. Y. Chai, Q. L. Zhang, J. H. Liu, C. X. He, ChemSusChem, 2018, 11, 3905-3910.

[66] K. Jiang, S. Siahrostami, T. Zheng, Y. Hu, S. Hwang, E. Stavitski, Y. Peng, J. Dynes, M. Gangisetty, D. Su, K. Attenkofer, H. Wang, Energy Environ. Sci., 2018, 11, 893-903.

[67] P. Jiang, J. Chen, C. Wang, K. Yang, S. Gong, S. Liu, Z. Lin, M. Li, G. Xia, Y. Yang, J. Su, Q. Chen, Adv. Mater, 2018, 30, 1705324.

[68] H. Kiuchi, R. Shibuya, T. Kondo, J. Nakamura, H. Niwa, J. Miyawaki, M. Kawai, M. Oshima, Y. Harada, Nanoscale Res. Lett., 2016, 11, 127.

[69] J. Wei, D. Zhou, Z. Sun, Y. Deng, Y. Xia, D. Zhao, Adv. Funct. Mater., 2013, 23, 2322-2328.

[70] K. Gao, B. Wang, L. Tao, B. V. Cunning, Z. Zhang, S. Wang, R. S. Ruoff, L. Qu, Adv. Mater., 2019, 31, e1805121.

[71] J. Wu, T. Sharifi, Y. Gao, T. Zhang, P. M. Ajayan, Adv. Mater., 2019, 31, e1804257.

[72] R. Kortlever, J. Shen, K. J. Schouten, F. Calle-Vallejo, M. T. Koper, J. Phys. Chem. Lett., 2015, 6, 4073-4082.

\section{氮硫共掺杂高比表面中空碳球的制备及其在电催化二氧化碳还原中的应用 李国栋, , 覃永杰 ${ }^{\mathrm{b}}$, 吴 玉 $^{\mathrm{a}, \mathrm{b}}$, 裴 蕾 ${ }^{\mathrm{b}}$, 胡 琪 $^{\mathrm{b}}$, 杨恒攀 ${ }^{\mathrm{b}}$, 张黔玲 ${ }^{\mathrm{b}}$, 刘剑洪 ${ }^{\mathrm{b}}$, 何传新 ${ }^{\mathrm{b}}$ * a中国科学技术大学化学物理系, 安徽合肥 230026 \\ b 深圳大学化学与环境工程学院, 广东深圳518060}

摘要: 化石燃料是现代能源体系的重要支柱, 其大量使用导致大气中 $\mathrm{CO}_{2}$ 浓度不断增加, 加剧了全球变暖和环境恶化. 因 此, 各国研究人员开发了大量技术手段以捕获和重新再利用 $\mathrm{CO}_{2}$ 这一丰富的碳资源. 其中, $\mathrm{CO}_{2}$ 电催化还原 $\left(\mathrm{CO}_{2} \mathrm{RR}\right)$ 技术在 
减少 $\mathrm{CO}_{2}$ 排放和将其转化为有用化学品等方面极具潜力. 但是, $\mathrm{CO}_{2} \mathrm{RR}$ 具有反应能垒高和动力学过程缓慢等特点, 进而限 制其转化效率, 故使用传统的贵金属材料( $\mathrm{Ag}, \mathrm{Au}, \mathrm{Cu}$ 及 $\mathrm{Pd}$ 等)作为 $\mathrm{CO}_{2} \mathrm{RR}$ 高效的催化剂. 然而, 贵金属材料的大规模应用受 限于它们成本高昂、稳定性差及环境毒性等缺点. 在各类可替代贵金属催化剂中, 碳材料因其廉价丰富、结构可调和导电 性高的特点在 $\mathrm{CO}_{2} \mathrm{RR}$ 应用上展现出诱人的前景, 因此, 探索合适的碳基催化剂在高效催化二氧化碳领域具有重要的研究价 值和意义.

本文通过简单有效的方法制备了一种氮硫共掺杂的高比表面的碳基催化剂(SZ-HCN)用于 $\mathrm{CO}_{2} \mathrm{RR}$. 首先利用表面活性 剂胶束Triton X-100作为模板诱导调控, 合成了具有中空结构的苯胺-吡咯共聚物, 并以此为碳前驱体, 通过一步热解共聚物 和硫粉获得 $\mathrm{N}$ 和 $\mathrm{S}$ 共掺杂多孔碳, 材料的高比表面积 $\left(1510 \mathrm{~m}^{2} \mathrm{~g}^{-1}\right)$ 得益于中空结构和 $\mathrm{ZnCl}_{2}$ 盐造成的纳米孔结构. 值得注意 的是, 高比表面的多孔结构且有效共掺杂N/S, 能提供更多的高活性催化位点和有利于相关反应物种的传输. 通过扫描电 子显微镜、高分辨透射电子显微镜、高角环形暗场-扫描透射-元素分布、 $\mathrm{N}_{2}$ 吸脱附等温分析及X射线光电子能谱等物理表 征证实了催化剂材料的中孔结构和N/S共掺杂组分. 进一步通过电化学测试分析和产物测试分析可知, 电催化剂SZ-HCN 在 $-0.60 \mathrm{~V}$ 还原 $\mathrm{CO}_{2}$ 为 $\mathrm{CO}$ 的法拉第效率高达 $93 \%$, 明显抑制竞争反应HER. 此外, 在 $-0.60 \mathrm{~V}$ 恒电位下连续 $20 \mathrm{~h}$ 测试, 依旧保 持稳定的电流密度 $\left(-5.2 \mathrm{~mA} \mathrm{~cm}{ }^{-2}\right)$ 和高的CO选择性, 显示了出色的耐久性和潜在应用性.

我们采用密度泛函数理论探究 $\mathrm{N}$ 和 $\mathrm{S}$ 掺杂的影响, 模拟计算可知, 相比单一 $\mathrm{N}$ 掺杂的催化剂, $\mathrm{N}, \mathrm{S}$ 共掺杂可以提供更多 的活性位点, 降低 $\mathrm{CO}_{2}$ 还原为 $\mathrm{CO}$ 反应中决速步生成 $\mathrm{COOH}^{*}$ 的吉布斯自由能垒, 进而提高催化活性. SZ-HCN催化剂展现出 的优异 $\mathrm{CO}_{2} \mathrm{RR}$ 活性和稳定性主要归因于: (1) N和S元素均匀掺杂到碳基体中, 两者的协同效应导致碳电荷再分布形成高活 性位点, 提高本征活性; (2)高比表面的多级孔结构提供了丰富的三相接触界面和有利的传输通道, 便于反应相关物种的快 速转移. 该碳基催化剂材料在替代贵金属应用于 $\mathrm{CO}_{2} \mathrm{RR}$ 展示了一定的潜力.

关键词: 高比表面; 中空结构; 碳基催化剂; $\mathrm{CO}_{2}$ 电还原; 电催化选择性

收稿日期: 2019-09-25. 接受日期: 2019-10-29. 出版日期: 2020-05-05.

*通讯联系人. 电话: (0755)26534173; 传真: (0755)26536141; 电子信箱: hecx@szu.edu.cn

基金来源：国家自然科学基金(21574084，21571131); 广东省自然科学基金(2017A040405066); 深圳市科技计划项目 (JCYJ20160308104704791, JCYJ20170818091657056).

本文的电子版全文由Elsevier出版社在ScienceDirect上出版(http://www.sciencedirect.com/science/journal/18722067). 